\title{
ARTHROBACTER LUTEUS NOV. SP. ISOLATED FROM BREWERY SEWAGE
}

\author{
TATSUHIKO KANEKO, KUNPEI KITAMURA AND \\ YASUSHI YAMAMOTO \\ The Research Laboratories of Kirin Brewery Co., Ltd., \\ Takasaki, Japan
}

(Received February 8, 1969)

\begin{abstract}
A group of bacteria isolated from brewery sewage was studied taxonomically. They were gram-positive, facultatively anaerobic, pleomorphic, branching, non-motile, non-sporulating, non-acid-fast, and catalase-positive rods $(0.6-1.0 \times 0.8-10.0 \mu)$. They formed cystites and showed bending-type cell division. They produced a yellow pigment and reduced nitrate, hydrolyzed starch, and liquefied gelatin. They produced acids from various carbohydrates.

These characteristics were compared with those of 18 strains of related microorganisms. The isolates seemed to belong to the genus Arthrobacter, but no corresponding species was found in the taxa appearing in Bergey's Manual (7th Ed.). The name Arthrobacter luteus was, therefore, newly proposed for these isolates.

While the new species was in accord with those of the genus Arthrobacter in basic characteristics, it also had similarities to some species of the genera Nocardia, Cellulomonas, Microbacterium, and Corynebacterium.

These observations suggested that the species occupied an intermediate position between the families Corynebacteriaceae and Actinomycetaceae.
\end{abstract}

During the course of a study on bacteria in brewery sewage, four strains of hitherto undescribed bacteria were isolated. This paper describes these new bacteria, which were identical with each other taxonomically and designated as Arthrobacter luteus.

\section{MATERIALS AND METHODS}

Microorganisms. Four strains, B-41, B-91, B-111-1, and B-621, were used. They were isolated from brewery sewage rich in discarded yeast. They resembled each other in their morphology, cultural characteristics, and gramstain, and seemed to belong to the same group. Eighteen strains which had some similarities to the group were used for comparative tests (Table 1).

Determination methods. Determination tests were carried out mainly by the methods described in "Jikken Nogei Kagaku, Jo-Kan" (1) and "Manual 
Table 1. List of microorganisms examined.

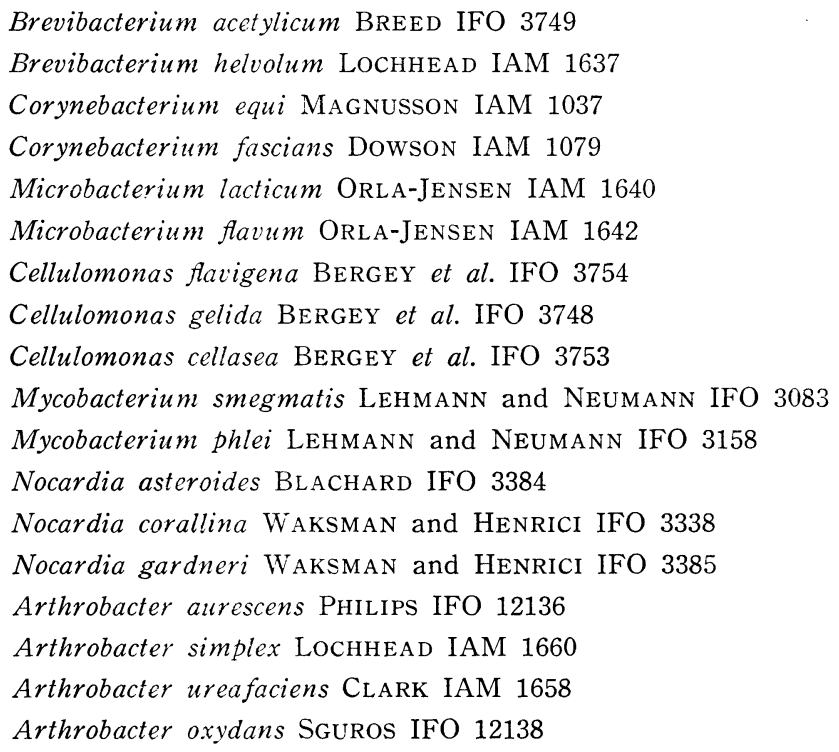

of Microbiological Methods" (2). The bacteria were identified according to "Bergey's Manual of Determinative Bacteriology" (3).

\section{RESULTS AND DISCUSSION}

\section{Gencral characteristics of the isolates}

All four strains had the same morphological, cultural, and physiological characteristics which may be summarized as follows.

The shape and size of cells in young cultures (nutrient agar, $30^{\circ}, 18 \mathrm{hr}$ ) were irregular, $0.6-1.0 \times 2.0-10.0 \mu$. Club-shaped, curved, swollen, and occasionally branched cells were observed. In old cultures (after $72 \mathrm{hr}$ ), the cells became short rods or cocci with an average size of $0.6-1.0 \times 0.8-1.0 \mu$. Cystities (4) were observed when cultures were grown at a higher temperature $37^{\circ}$. The cells were non-motile, non-sporulating, and non-acid-fast. Cells were gram-positive in young cultures. In old cultures, gram-negative cells which sometimes included gram-positive granules were observed besides gram-positive cells. In young cultures on a nutrient agar plate $\left(30^{\circ}, 3\right.$ days), the edge of the colonies was entire, but deep colonies with filamentous edge were formed in old cultures (after 7 days). They produced a yellow pigment, reduced nitrate, hydrolyzed starch, but did not decompose cellulose. The catalase reaction was positive. Acids but no gas was formed from various carbohydrates. They grew in peptone broth containing up to $7 \%$ sodium chloride. They 
were facultatively anaerobic.

From these characteristics, they seemed to belong to Family XII Corynebacteriaceae described in Bergey's Manual (7th Ed.). These characteristics of the isolates were compared with those of related organisms.

Comparison of the isolates with related organisms

1) Relation to Brevibacterium BREED

According to Bergey's Manual (7th Ed., 1957), bacteria of the genus Brevibacterium are characterized as being gram-positive, unbranched short rods. This genus was established by BREED for some bacteria whose taxonomical positions he found obscure with little phylogenic consideration. Consequently, as pointed out by Skerman (5), Komagata et al. (6), and Kinoshita et al. (7), the generic concept of Brevibacterium is not clear.

Brev. acetylicum IFO 3749 resembled the isolates in its morphological changes from rods to coccoid cells, tolerance for sodium chloride, ability to hydrolyze starch, and ferment sugars, but was different in its inabilities both to form branched cells and to reduce nitrate.

On the other hand, Brev. helvolum IAM 1637 resembled the isolates in forming branched cells in young cultures, but was different in the absence of morphological changes and inabilities to reduce nitrate, hydrolyze starch. and ferment sugars.

In view of the above facts, it may be reasonable not to include the isolates in the genus Brevibacterium.

2) Relation to Corynebacterium LEHMANN and NEUMANN

When LEHMANN and NEUMANN first distinguished the genus Corynebacterium in 1896, the genus was characterized by its pathogenic effect on animals, irregular cell shape, absence of endospores, immotility, and grampositivity. The genus, however, now includes bacteria with a wide range of characteristics such as pathogenicity to plants and being motile $(8)$.

From a historical viewpoint, pleomorphism seems to be a generic characteristic of the genus.

Recently, Komagata et al. (9) found that most of the bacteria in this genus showed snapping-type cell division, and they proposed to regard this characteristic as a taxonomic one.

Coryn. fascians IAM 1079 was gram-positive, pleomorphic, and formed branched cells. Cell division of the organism was snapping-type unlike that of the isolates. The outline of the cells appeared sharper than that of the cells of the isolates. It did not have the physiological activities of the isolates.

Coryn. equi IAM 1037 was similar to the isolates morphologically except for the snapping-type cell division. It did not liquefy gelatin, ferment sugars except glucose, or hydrolyze starch.

On the basis of the above-mentioned differences, the isolates would not belong to the genus Corynebacterium. 
3) Relation to Cellulomonas BERGEY et al. emend. ClARK

Bacteria of the genus Cellulomonas are characterized by gram variability, pleomorphism, and ability to decompose cellulose (3). However, three strains of Cellulomonas tested did not decompose cellulose. Komagata et al. (6) have also reported that $C$. $u d a$ ATCC 491 and C. gelida ATCC 488 did not decompose cellulose. As many authentic strains have no cellulase activity, the generic concept of the genus may remain to be elucidated.

Three strains used were very similar to the isolates in their pleomorphism, utilization of carbohydrates, and reduction of nitrate, but they were different from the isolates in their gram variability, slow growth, and intolerance to sodium chloride.

Though there are similarities between the isolates and some members of Cellulomonas, it is inappropriate at present to classify the isolates in the genus Cellulomonas, since cellulase activity is a fundamental characteristic of this genus in the current taxonomical system.

4) Relation to Microbacterium ORLA-JENSEN

In Bergey's Manual (7th Ed.), Microbacterium is characterized by its heat resistance in skimmed milk and its ability to produce lactic acid, but there has been a recent tendency to regard Microbacterium as a general term for thermodural strains of Corynebacterium rather than as an independent genus $(7,8,10)$.

As Microb. flavum IAM 1642 and Microb. lacticum IAM 1640 were pleomorphic and formed branched cells, these two strains were not in accord with Microbacterium in the sense of SKERMAN's description (5), but had some similarities to Arthrobacter or Corynebacterium. Moreover, their heat tolerance estimated by both the capillary method and the test tube method (11) was found to be lower than SKERMAN's description.

These two strains were similar to the isolates in pleomorphism and branching, but they were distinctly different from the isolates in their cultural characteristics such as pigment production and appearance of the colonies.

Since the isolates did not conform to SKERMAN's description and they were also different from the two thermosensitive strains of this genus, the isolates do not belong to this genus.

5) Relation to Mycobacterium LeHMANn and NeumanN

Mycobacterium is characterized as being saprophytic or parasitic, grampositive, aerobic, acid-fast, and of rudimentary branching (3).

The isolates were, to some extent, similar to some strains of Mycobacterium described in Bergey's Manual (7th Ed.) in their pleomorphism, but they were distinctly different from the latter in their facultative anaerobic and nonacid-fast characteristics.

Mycob. smegmatis IFO 3083 and Mycob. phlei IFO 3158 were different from the isolates in morphology, and in aerobic and acid-fast characteristics. Therefore, the isolates do not belong to the genus Mycobacterium.

6) Relation to Nocardia TREvisan 
Similarities between the isolates and some strains of Nocardia in such characteristics as gram staining, pleomorphism, branching of cells, and filamentous deep colony, led us to investigate their relation to Nocardia.

Nocardia is characterized by being aerobic, gram-positive, and producing mycelia but some strains of Nocardia show morphological changes in their life cycle like Corynebacterium or Arthrobacter (3, 5, 10, 12).

Although the isolates seemed to be similar to some strains of Nocardia in their morphological changes during the life cycle and in their formation of colonies with filamentous edge on nutrient agar in old cultures, they did not seem to be a member of the Nocardia because they did not form such clear mycelia as Nocardia.

The three strains of Nocardia tested conformed to the description in Bergey's Manual (7th Ed.) in producing mycelia, forming clearly branching cells, and being physiologically inactive. They were definitely different from the isolates.

7) Relation to Arthrobacter CONN and DIMMICK

CONN and DimMICK (13) studied a soil bacterium named Bacterium globiforme and found that it belonged to neither the Mycobacterium nor Corynebacterium and first proposed the genus Arthrobacter.

Bacteria of the genus Arthrobacter were, at that time, characterized as follows: “... strongly aerobic forms, showing rather complicated morphological life cycles, including rods, cocci, club, and branched forms, non-acid-fast, gram variable, able to live on inorganic nitrogen without added growth accessory substances, typically soil organisms" (13).

The genus Arthrobacter has been recognized generally $(3,14,15)$ despite JENSEN's protest $(8)$, and the concept of the genus has extended in respects to nutritional requirement $(16,17)$, gram stain $(18,19)$, and sources $(15,19)$.

Lately, there has been a tendency to stress morphological characteristics such as pleomorphism and formation of cystites $(3-5,20)$. Komagata et al. (9) found that most species of the genus Arthrobacter showed bending-type cell division, and they proposed to regard this characteristic as a taxonomic one.

All four authentic strains in this genus were similar to the isolates in their pleomorphism, cystite formation, and bending-type cell division. With gram stain, three strains except $A$. simplex IAM 1660 were positive like the isolates. On the other hand, these four strains were different from the isolates in their inability to ferment various carbohydrates and to form deep colonies.

Because the formation of branching cells and cystites, morphological changes in the life cycle, and bending-type cell division were considered to be more fundamental characteristics of the genus Arthrobacter in taxonomy than formation of deep colonies and ability to ferment sugars, the authors thought it reasonable to classify the isolates in this genus.

In the genus Arthrobacter, the isolates differed from $A$. tumescens, $A$. 
Table 2. Differences between $A$. luteus nov. sp. and related bacteria.

\begin{tabular}{|c|c|c|c|c|c|c|}
\hline & \multicolumn{2}{|c|}{ A. luteus nov. sp. } & \multicolumn{2}{|c|}{$\begin{array}{l}\text { A. oxydans } \\
\text { IFO } 12138\end{array}$} & \multicolumn{2}{|c|}{$\begin{array}{l}\text { A. aurescens } \\
\text { IFO } 12136\end{array}$} \\
\hline Nutrient broth & \multicolumn{2}{|c|}{$\begin{array}{l}\text { Moderate growth, } \\
\text { yellow sediment }\end{array}$} & \multicolumn{2}{|c|}{$\begin{array}{l}\text { Abundant growth, } \\
\text { ring, white } \\
\text { sediment }\end{array}$} & \multicolumn{2}{|c|}{$\begin{array}{l}\text { Moderate growth, } \\
\text { cream-colored } \\
\text { sediment }\end{array}$} \\
\hline Glutamate agar slant & \multirow{2}{*}{\multicolumn{2}{|c|}{$\begin{array}{l}\text { Plumose, white } \\
\text { Scanty growth, } \\
\text { white }\end{array}$}} & \multicolumn{2}{|c|}{ Filiform, white } & \multicolumn{2}{|c|}{ Filiform, yellow } \\
\hline Nicotin agar slant & & & \multicolumn{2}{|c|}{$\begin{array}{l}\text { Abundant growth, } \\
\text { blue pigment }\end{array}$} & \multicolumn{2}{|c|}{$\begin{array}{l}\text { Growth slow and } \\
\text { sparse }\end{array}$} \\
\hline Litmus milk & \multicolumn{2}{|c|}{ Acid, coagulation } & \multicolumn{2}{|c|}{$\begin{array}{l}\text { Slow peptonization, } \\
\text { alkaline }\end{array}$} & \multicolumn{2}{|c|}{$\begin{array}{l}\text { Pale yellow ring, } \\
\text { alkaline }\end{array}$} \\
\hline Hydrogen sulfide & \multicolumn{2}{|c|}{ Not produced } & \multicolumn{2}{|c|}{ Not produced } & \multicolumn{2}{|c|}{ Produced } \\
\hline Fermentability & Acid & Gas & Acid & Gas & Acid & Gas \\
\hline Arabinose & + & - & - & - & - & - \\
\hline Xylose & + & - & - & - & - & - \\
\hline Glucose & + & - & + & - & \pm & - \\
\hline Mannose & + & - & - & - & - & - \\
\hline Fructose & + & - & + & - & - & - \\
\hline Galactose & + & - & - & - & - & - \\
\hline Lactose & + & - & - & - & - & - \\
\hline Maltose & + & - & - & - & - & - \\
\hline Saccharose & + & - & + & - & \pm & - \\
\hline Mannitol & - & - & - & - & - & - \\
\hline Glycerol & + & - & - & - & - & - \\
\hline Inulin & + & - & - & - & - & - \\
\hline Starch & + & - & - & - & - & - \\
\hline $\begin{array}{l}\text { Optimum temperature } \\
\text { for growth }\left(^{\circ}\right)\end{array}$ & \multicolumn{2}{|c|}{$30-37$} & \multicolumn{2}{|c|}{25} & \multicolumn{2}{|c|}{$20-32$} \\
\hline Source & \multicolumn{2}{|c|}{ Brewery sewage } & \multicolumn{2}{|c|}{ Tobacco leaves } & \multicolumn{2}{|l|}{ Soil } \\
\hline
\end{tabular}

citreus, and $A$. terregens in that they could utilize ammonium salts as a sole source of nitrogen. They differed from A. globiformis, $A$. pascens, and $A$. simplex in chromogenic character. They were also different from $A$. ureafaciens in that they could hydrolyze starch and reduce nitrate. Although the isolates were considered to be similar to $A$. oxydans and $A$. aurescens in that they utilized nitrate and ammonium salts, hydrolyzed starch, and reduced nitrate, they were found to be different from the two strains in the characteristics shown in Table 2.

The isolates were, therefore, regarded as a new species and the name Arthrobacter luteus was proposed for them.

Photomicrographs of the representative strain B-111-1 on nutrient agar slant are presented in Fig. 1. 


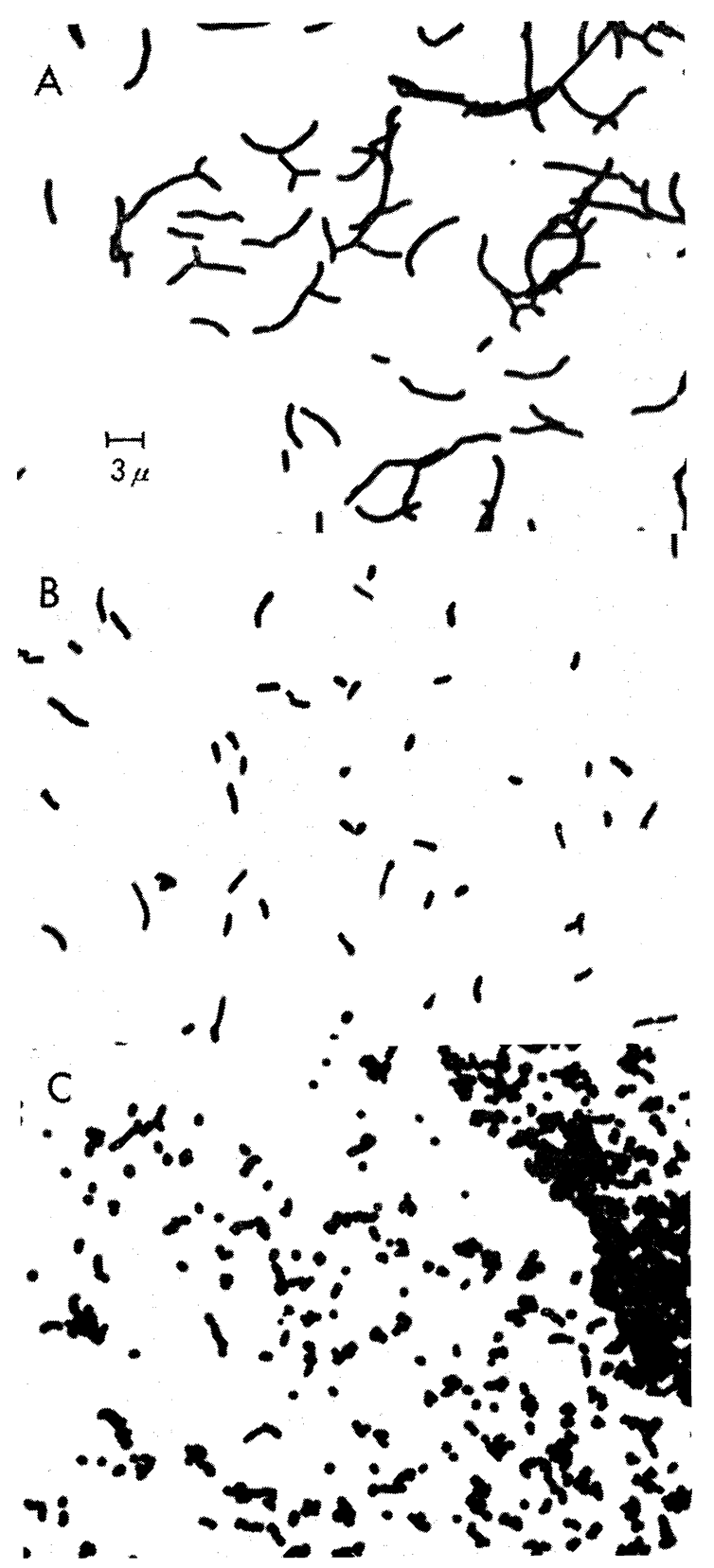

Fig. 1. Photomicrographs of Arthrobacter luteus B-111-1.

Grown on nutrient agar slant for (A) $14.5 \mathrm{hr}$, (B) $24 \mathrm{hr}$, and (C) $48 \mathrm{hr}$ at $30^{\circ}$. Gram stain. 

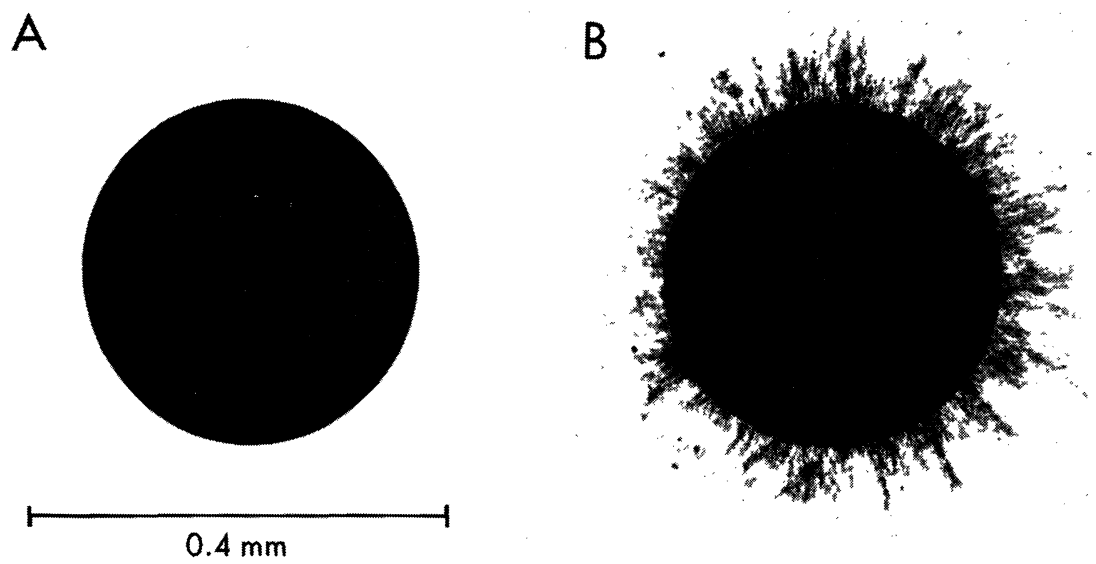

Fig. 2. Colonies of Arthrobacter luteus B-111-1.

Grown on nutrient agar plate for (A) 3 days and (B) 10 days at $30^{\circ}$.

The type culture of this species is Arthrobacter luteus nov. sp. B-111-1 deposited with the Fermentation Research Institute, the Ministry of International Trade and Industry, Inage, Chiba City.

The taxonomy of the family Corynebacteriaceae has been studied in more detail recently with increase in practical use of members of this family ( 7 , $11,21-24)$.

As mentioned above, A. luteus has a slight similarity to the genus Nocardia in that it produces rigid deep colonies with rudimentary filamentous edge under the surface colonies when cultured on nutrient agar plate at $30^{\circ}$ for more than 7 days (Fig. 2). It also has similarity to some species of the genera Cellulomonas, Microbacterium, or Corynebacterium in that it produces acids from various carbohydrates fermentatively on the test proposed by HUGH and LEIFSON (25).

From these characteristics, $A$. luteus may be an intermediate form between the families Corynebacteriaceae and Actinomycetaceae.

Description of Arthrobacter luteus nov. sp.

Strains: B-41, B-91, B-111-1 and B-621.

Type culture: B-111-1.

Rods, 0.6 to 1.0 by 0.8 to 10.0 micra. Pleomorphic. Curved, swollen, clubshaped cells and rudimentary branching of cells are observed. In old cultures, the cells become short rod form or coccoid form, measuring 0.6 to 0.8 by 0.8 to 1.0 micra and sometimes irregular in shape. Cystites are observed when cultured at $37^{\circ}$. Spore not formed. Gram-positive in young cultures. In old 
cultures, gram-negative cells which sometimes include gram-positive granules are observed besides gram-positive cells. Non-acid-fast.

Nutrient agar colonies: Circular, smooth, entire, raised, glistening, yellow, butyrous. In old cultures, filamentous deep colonies are observed.

Glutamate agar colonies (26): Growth scant, circular, smooth, filamentous, flat, white, opaque. The colonies develop little better in the medium than on the surface of the medium.

Nutrient agar slant: Growth moderate, filiform, glistening, smooth, yellow: In old cultures, the edge becomes filamentous.

Glutamate agar slant: Growth scant, plumose, white, opaque, medium unchanged.

Nutrient broth: Moderate turbidity with yellow sediment, no pellicle.

Nutrient gelatin stab: Slow liquefaction.

B.C.P. milk: Acid, coagulation.

Nitrite produced from nitrate.

Indole not produced.

Hydrogen sulfide not produced.

Starch hydrolyzed.

Methyl Red test: Weakly positive.

Voges-Proskauer test: Negative.

Ammonia not produced from peptone.

Potato: Moderate growth, yellow.

Acid but no gas from arabinose, xylose, glucose, mannose, fructose, galactose, lactose, maltose, saccharose, trehalose, sorbitol, glycerol, salicin, $\alpha$-methylglucoside, inulin, dextrin, and starch. No acid and no gas from mannitol, raffinose, rhamnose, and inositol.

Succinate is utilized as a sole carbon source but citrate is not utilized.

Paraffin is utilized but phenol or $m$-cresol is not utilized.

Urease slightly produced.

Cellulose not attacked.

Blue pigment is not produced on nicotin agar slant.

$\mathrm{NaCl}$ broth: Good growth up to $7 \% \mathrm{NaCl}$, growth in a few cases in $8, c$. Optimum temperature for growth: 30 to $37^{\circ}$. No growth at $52^{\circ}$.

Optimum pH for growth: Between 7.0 and 8.0.

Catalase: Positive.

Did not survive for $10 \mathrm{~min}$ at $72^{\circ}$ in skimmed milk.

Facultatively anaerobic.

Source: Brewery sewage.

The authors wish to express their sincere thanks to Dr. Y. Okuda, member of the Japan Academy, Prof. Dr. T. Uemura, the Institute of Applied Microbiology, the University of Tokyo, Dr. K. Sudo, the National Institute of Animal Health, Prof. Dr. T. Arai, the Institute of Food Microbiology, Chiba University, Dr. S. Takahashi, the Institute of Tuberculosis, and Dr. K. Komagata, the Central Research Laboratories, Ajinomoto Co., 
Inc., for their helpful suggestions throughout this study. They wish to express their thanks to the Institute for Fermentation, Osaka, for the kind supply of microorganisms. They would like to thank Mr. M. Tokikuni, President, and Mr. T. Suzuki, the Managing Director, of Kirin Brewery Co., Ltd., for giving them the opportunity to publish this paper. They are also grateful to Dr. Y. Kuroiwa, Director of this Research Laboratories, for his kind guidance and encouragement.

\section{REFERENCES}

1) Jikken Nogei Kagaku, Jo-kan, ed. by Department of Agricultural Chemistry, Faculty of Agriculture, the University of Tokyo, Asakura Publ. Co., Tokyo (1960), p. 186, in Japanese.

2) M.J. Pelczar, Jr., Manual of Microbiological Methods, McGrow-Hill Book Co., Inc., New York (1957).

3. R.S. Breed, E.G.D. MURRAY and N.R. Smith, Bergey's Manual of Determinative Bacteriology, 7th Ed., Williams and Wilkins Co., Baltimore (1957).

4 I.L. Stevenson, Can. J. Microbiol., 9, 467 (1963).

5: V.B.D. Skerman, A Guide to the Identification of the Genera of Bacteria, Williams and Wilkins Co., Baltimore (1959).

6) K. Komagata, H. Izzuka and C. Uchino, Nippon Nogei Kagaku Kaishi, 38, 503 (1964).

j) S. Kinoshita, S. Itagaki and K. Nakayama, Amino Acids, 2, 42 (1960).

8) H.L. Jensen, Ann. Rev. Microbiol., 6, 77 (1952).

9) K. Komagata, H. Ogawa and K. Yamada, Proc. 38th Ann. Meet., Agr. Chem. Soc. Japan, p. 95 (1967), abstract in Japanese.

10) H.L. Jensen, J. Appl. Bacteriol., 29, 13 (1966).

11) K. Takayama, S. ABE and S. Kinoshita, Nippon Nogei Kagaku Kaishi, 39, 328 (1965).

12) J.N. Adams and N.M. McClung, J. Bacteriol., 84, 206 (1962).

13) H.J. Conn and I. Dimmick, J. Bacteriol., 54, 291 (1947).

14) L.E. SACKS, J. Bacteriol., 67, 342 (1954).

15) P.L. Sguros, J. Bacteriol., 69, 28 (1955).

16) J.G. Morris, J. Gen. Microbiol., 22, 564 (1960).

17) E.C.N. Chan and I.L. Stevenson, Can. J. Microbiol., 8, 403 (1962).

18) H. Iizuka and K. Komagata, J. Gen. Appl. Microbiol., 11, 1 (1965).

19) E.G. Mulder and J. Antheunisse, Ann. Pasteur, 105, 46 (1963).

20) E.G. Mulder, A.D. Adamse, J. Antheunisse, M.H. Deinerma, J.W. Woldenorp and L.P.T.M. Zevenhuizen, $J$. Appl. Bacteriol., 29, 44 (1966).

21) S. DoI and Y. Kaneko, Amino San, 2, 26 (1960).

22) K. Miyai, I. Tsuruo, R. Kodaira, S. Hayakawa, T. Akimoto and K. Goto, Nippon Nogei Kagaku Kaishi, 37, 32 (1963).

23) H. Takahashi, S. Hayakawa, M. Shibukawa, T. Osawa and K. Miyai, Nippon Nogei Kagaku Kaishi, 41, 560 (1967).

24) T. Harada, K. Seto and Y. Murooka, Hakko Kôgaku Zasshi, 46, 169 (1968).

25) R. Hugh and E. Leifson, J. Bacteriol., 66, 24 (1953).

26) K. Komagata, J. Gen. Appl. Microbiol., 7, 282 (1961). 